\title{
Bibliometric analysis of multi-language veterinary journals
}

\section{Análise bibliométrica de revistas veterinárias multilíngues}

\author{
Erwin KRAUSKOPF ${ }^{1,2}$ \\ Fernanda GARCIA ${ }^{2}$ \\ Robert FUNK ${ }^{3}$
}

\begin{abstract}
The purpose of this study was to investigate the association between language and total number of citations found among documents in journals written in English and other languages. We selected all the journals clustered together in the Journal Citation Reports 2014 under the subject category "Veterinary Sciences" and downloaded all the data registered between 19942013 by Web of Science for the journals that stated publishing documents in languages other than English. We classified each of these journals by quartile and extracted information regarding their impact factor, language(s) stated, country of origin, total number of documents published, total number of reviews published, percentage of documents published in English and the quartile in which each journal ranked. Of the 48,118 documents published by the 28 journals analyzed, $55.8 \%$ were published in English. Interestingly, although most of the journals state being multi-language, most documents published in quartile 1 journals were in English (an average of 99.2\%), while the percentage was 93.1\% in quartile 2 journals, $62.1 \%$ in quartile 3 journals and $27.4 \%$ in quartile 4 journals. We also confirmed that citation distribution in these journals was highly skewed. The results of this study suggest that journals should consider adopting English as the main language as this will increase citation counts and the impact factor of the journal.
\end{abstract}

Keywords: Bibliometric. Impact factor. Multi-language. Scientific journal. Veterinary science.

\section{Resumo}

O objetivo deste estudo foi investigar a associação entre a escolha do idioma e o número de citações, a partir da análise de revistas publicadas em inglês e em outras línguas. Foram selecionadas as revistas agrupadas no Journal Citation Reports de 2014 sob a categoria "ciências veterinárias", bem como os dados registrados na Web of Science entre 1994 e 2013 sobre as revistas que declararam documentos publicados em outro idioma que não o inglês. A seguir, as revistas foram classificadas por quartil, extraindo-se informações acerca de: índice de impacto, idioma(s) declarado(s), país de origem, número total de documentos publicados, número total de revisões publicadas, porcentagem de documentos publicados em inglês e quartil em que cada jornal foi classificado. Dos 48.118 documentos editados por 28 revistas analisadas, 55,8\% foram publicados em inglês. Interessantemente, apesar de a maioria dessas revistas se declarar multilíngue, a maior parte dos documentos publicados em revistas quartil 1 empregou o inglês (uma média de 99,2\%), enquanto para as revistas quartil 2 esse índice foi de $93,1 \%$, para quartil 3 foi de $62,1 \%$, e para quartil 4 foi de $27,4 \%$. A pesquisa também confirmou que a distribuição das citações nessas revistas foi altamente distorcida. Os resultados do estudo sugerem que as revistas deveriam adotar o inglês como idioma principal, o que faz aumentar o número de citações e o fator de impacto da revista.

Palavras-chave: Bibliométrica. Fator de impacto. Multilíngue. Revista científica. Ciência veterinária.

\footnotetext{
$\overline{1}$ Universidad Andres Bello, Facultad de Ciencias Biológicas, Departamento de Ciencias Biológicas. Republica, 217, Piso 2, Santiago, Chile. Correspondencia para/Correspondence to: E. KRAUSKOPF.E-mail:<erwin.krauskopf@unab.cl>.

2 Fundación Ciencia \& Vida. Santiago, Chile.

3 Universidad de Chile, Instituto de Asuntos Públicos. Santiago, Chile.
} 


\section{Introduction}

'Publish or perish' has become an expression that best describes the situation of many researchers around the world. Currently, the number of articles published in journals with a high impact factor has become a major criterion for academic success as these account towards the research productivity of scientist, along with the number of articles considered when applying for a research grant. However, publishing on a top-tier journal is becoming increasingly more difficult for a number of reasons. The number of researchers has increased dramatically in recent years, while the availability of research funds has diminished (RABESANDRATANA, 2015; ZHOU, 2015). Additionally, English is the dominating language in top-tier journals. This is a significant barrier for a large number of researchers who are from non-English speaking countries. It is a well-known fact that Chinese and Spanish are the two most-spoken native languages in the world (LEWIS et al., 2016). As a result, many of these researchers depend on peer-reviewed journals that publish documents in languages other than English, although their non-English documents have a smaller possibility of being cited (VASCONCELOS et al., 2007). This scenario is common to all scientific fields of study, including veterinary science.

Veterinary science has contributed greatly to medicine, playing an important role in food safety and public health, preventing the emergence of outbreaks such as food and mouth diseases and H1N1 (KLOEZE et al., 2013; KNIGHT-JONES; RUSHTON, 2013). Furthermore, veterinary research includes research on prevention, control, diagnosis, and treatment of animal diseases as well as basic biology, welfare, and animal care. The outcome of these studies is published in peer-reviewed journals that are clustered together under the category "Veterinary Sciences" (by Thomson Reuters) and "Veterinary" (by Scopus). Depending on the database selected, the quantity of veterinary journals varies from 133 in Thomson Reuters to 215 for Scopus.

In this study, we investigated the impact of the language of the publications on citation frequency of all journals clustered together under the subject category "Veterinary Sciences" by the Journal Citation Reports (JCR) 2014 and state publishing documents in non-English languages.

\section{Methodological procedures}

The JCR 2014 database was used to download all the journals that were clustered under the subject category "Veterinary sciences". Information about every journal was collected and a subset of journals was built using only those that stated being multilanguage or published documents in other languages other than English.

The Web of Science (WoS) database was used to retrieve all the records associated with the journals within the years 1994-2013. Data was processed using Sequel Pro and Excel.

\section{Results}

The JCR 2014 listed 133 journals under the subject category "Veterinary Sciences" with a maximum impact factor of 2.944 and a median of 0.889. Among these journals, we identified 36 that published articles in languages other than English. Table 1 shows production data for these journals between 19942013 (we excluded 8 from this study because they were registered by WoS after 1994), such as impact factor, language(s) stated, country of origin, total number of documents published, total number of reviews published, percentage of documents published in English and the Quartile (Q) in which each journal ranked. In simple terms, all journals were sorted according to their impact factor data in each of the subject categories, generating quartile rankings. Therefore, Q1 (first quartile) represents the top 25\% of the impact factor distribution for a specific subject category, Q2 among the top 25\% and 50\%, Q3 among the top 50\% and 75\% and Q4 lists those below 25\%. Data from Table 1 shows that most journals are listed in the fourth quartile instead of the first quartile. 
Table 1. List of journals within the subject category "Veterinary Sciences".

\begin{tabular}{|c|c|c|c|c|c|c|c|c|}
\hline $\mathrm{N}^{\circ}$ & Journal title & IF2014 & Country Origin & Language(s) & Q & \# Docs & \# Rev & $\begin{array}{l}\% \text { Docs } \\
\text { English }\end{array}$ \\
\hline 1 & $\begin{array}{l}\text { Comparative Immunology Microbiology and } \\
\text { Infectious Diseases }\end{array}$ & 2,015 & England & Multi-language & Q1 & 773 & 42 & 98.2 \\
\hline 2 & Avian Pathology & 1,639 & England & Multi-language & Q1 & 1,490 & 73 & 99.7 \\
\hline 3 & Reproduction in Domestic Animals & 1,515 & Germany & Multi-language & Q1 & 7,405 & 64 & 99.7 \\
\hline 4 & Acta Veterinaria Scandinavica & 1,377 & Denmark & Multi-language & Q2 & 1,192 & 20 & 100.0 \\
\hline 5 & Fish Pathology & 1,064 & Japan & Multi-language & Q2 & 745 & 10 & 78.9 \\
\hline 6 & $\begin{array}{l}\text { Canadian Journal of Veterinary Research-Revue } \\
\text { Canadienne de Recherche Veterinaire }\end{array}$ & 1,022 & Canada & Multi-language & Q2 & 1,022 & 9 & 99.7 \\
\hline 7 & Experimental animals & 0,965 & Japan & Multi-language & Q2 & 1,087 & 59 & 95.9 \\
\hline 8 & $\begin{array}{l}\text { Revue Scientifique et Technique-Office International } \\
\text { Des Epizooties }\end{array}$ & 0,910 & France & Multi-language & Q2 & 757 & 54 & 90.8 \\
\hline 9 & Japanese Journal of Veterinary Research & 0,889 & Japan & Multi-language & Q3 & 262 & 24 & 100.0 \\
\hline 10 & Revista Brasileira de Parasitologia Veterinaria & 0,869 & Brazil & Multi-language & Q3 & 520 & 11 & 71.5 \\
\hline 11 & Berliner und Munchener Tierarztliche Wochenschrift & 0,819 & Germany & Multi-language & Q3 & 1,484 & 38 & 26.4 \\
\hline 12 & Inra Productions Animales & 0,726 & France & French & Q3 & * & * & N/A \\
\hline 13 & Wiener Tierarztliche Monatsschrift & 0,600 & Austria & German & Q3 & 998 & 51 & 23.5 \\
\hline 14 & $\begin{array}{l}\text { Canadian Veterinary Journal-Revue Veterinaire } \\
\text { Canadienne }\end{array}$ & 0,516 & Canada & Multi-language & Q3 & 3,664 & 41 & 98.9 \\
\hline 15 & Acta Veterinaria Brno & 0,469 & Czech Republic & Multi-language & Q3 & 1,302 & 12 & 99.9 \\
\hline 16 & Schweizer Archiv Fur Tierheilkunde & 0,451 & Switzerland & Multi-language & Q3 & 1,534 & 31 & 14.2 \\
\hline 17 & Vlaams Diergeneeskundig Tijdschrift & 0,417 & Belgium & Multi-language & Q4 & 826 & 93 & 40.6 \\
\hline 18 & Pesquisa Veterinaria Brasileira & 0,362 & Brazil & Multi-language & Q4 & 1,531 & 16 & 26.0 \\
\hline 19 & $\begin{array}{l}\text { Revista Brasileira de Zootecnia-Brazilian Journal of } \\
\text { Animal Science }\end{array}$ & 0,359 & Brazil & Multi-language & Q4 & 4,432 & 3 & 19.1 \\
\hline 20 & Revue de Medecine Veterinaire & 0,323 & France & French & Q4 & 1,995 & 144 & 59.7 \\
\hline 21 & Veterinaria Mexico & 0,323 & Mexico & Multi-language & Q4 & * & * & N/A \\
\hline 22 & Archivos de Medicina Veterinaria & 0,306 & Chile & Spanish & Q4 & 726 & 74 & 14.0 \\
\hline 23 & Journal of The Hellenic Veterinary Medical Society & 0,267 & Greece & Greek & Q4 & * & * & $\mathrm{N} / \mathrm{A}$ \\
\hline 24 & Kafkas Universitesi Veteriner Fakultesi Dergisi & 0,258 & Turkey & Turkish & Q4 & 1,147 & 24 & 64.7 \\
\hline 25 & Turkish Journal of Veterinary \& Animal Sciences & 0,242 & Turkey & Multi-language & Q4 & 2,129 & 17 & 62.1 \\
\hline 26 & $\begin{array}{l}\text { Arquivo Brasileiro de Medicina Veterinaria e } \\
\text { Zootecnia }\end{array}$ & 0,240 & Brazil & Multi-language & Q4 & 2,991 & 0 & 20.2 \\
\hline 27 & Acta Scientiae Veterinariae & 0,222 & Brazil & Portuguese & Q4 & * & * & N/A \\
\hline 28 & Ankara Universitesi Veteriner Fakultesi Dergisi & 0,219 & Turkey & Turkish & Q4 & * & * & N/A \\
\hline 29 & $\begin{array}{l}\text { Medycyna Weterynaryjna - Veterinary Medicine - } \\
\text { Science and Practice }\end{array}$ & 0,218 & Poland & Multi-language & Q4 & * & * & N/A \\
\hline 30 & Pferdeheilkunde & 0,190 & Germany & German & Q4 & 1,439 & 19 & 35.6 \\
\hline 31 & Revista Cientifica-Facultad de Ciencias Veterinarias & 0,190 & Venezuela & Multi-language & Q4 & 1,311 & 3 & 8.9 \\
\hline 32 & Magyar Allatorvosok Lapja & 0,185 & Hungary & Multi-language & Q4 & 2,969 & 139 & 3.0 \\
\hline 33 & Tieraerztliche Umschau & 0,120 & Germany & German & Q4 & 880 & 6 & 1.4 \\
\hline 34 & Kleintierpraxis & 0,079 & Germany & German & Q4 & 1,507 & 39 & 0.9 \\
\hline 35 & Medicina Veterinaria-Recife & 0,022 & Brazil & Portuguese & Q4 & * & * & N/A \\
\hline 36 & Ippologia & 0,000 & Italy & Italian & Q4 & * & * & $\mathrm{N} / \mathrm{A}$ \\
\hline
\end{tabular}

Source: Prepared by the authors (2016) based on data Journal Citation Reports ( 2014) and Web of Science (2014).

Note: *Indicates journals that were registered by WoS after 1994, therefore were not considered for this study. Data used to build table was extracted from JCR 2014 and WoS. The impact factor, language, country of origin and quartile were obtained from JCR 2014. The total amount of documents published by each journal and the percentage of documents published in English between 1994-2013 was obtained using WoS.

Q: Quartile; N/A: not available; JCR: Journal Citation Reports; Wos: Web of Science. 
The impact factor, language, country of origin and quartile were obtained from JCR 2014. The total amount of documents published by each journal and the percentage of documents published in English between 1994-2013 was obtained using WoS.

\section{Country of origin and editorial management}

The geographical distribution of the journals listed on Table 1 reveals a high concentration of European journals (52.8\%), followed by American journals (27.8\%). A total of 18 countries are represented in this set of journals, in which Brazil is the country with the highest number of journals (6). Since there was a high presence of European countries, we became interested in the editorial board behind each journal. Our analysis revealed that the three journals ranked Q1 from Table 1 are managed by large commercial publishers (Elsevier, Taylor \& Francis, and Wiley-Blackwell), as well as Acta Veterinaria Scandinavia (managed by BioMed Central), Berliner und Munchener Tierarztliche Wochenschrift (managed by Schluetersche $\mathrm{GmbH}$ und $\mathrm{Co}$ ), Wiener Tierarztliche Monatsschrift (managed by BWK Public Relations) and Schweizer Archiv fur Tierheilkunde (managed by Hogrefe Publishing Group). None of the journals that were ranked in the fourth quartile are managed by large commercial publishers. The other 29 journals are managed by academic boards such as universities and scientific associations.

\section{Language}

Interestingly, despite these journals stating themselves as multi-language, most of the documents published in Q1 journals between 1994-2013 were in English (an average of 99.2\%) (Table 1). As for the other quartiles, their averages were $93.1 \%$ for Q2, 62.1\% for Q3 and 27.4\% for Q4. In general, journals that publish documents mainly in English have a higher impact factor as previously described (CAVALCANTI-LIRA et al., 2013; CHRISTOPHER; MARUSIC, 2013; VINTHER; ROSENBERG, 2012). We considered investigating the contribution of the four most productive Englishspeaking countries according to Scimago (SCIMAGO, 2015) in the generation of these documents. As shown in Table 2, researchers from either Australia, Canada, England or the United States wrote more than $73 \%$ of the documents published in two Canadian journals. In contrast, the input of these four countries was below $10 \%$ in 21 of the veterinary journals, although ten of these journals were European. In fact, two of the European journals published $99.9 \%$ and $100 \%$ of the documents in the English language.

We also established the percentage of documents developed by cooperative work of authors from different countries. As expected, Q1 journals obtained the highest percentages (on average 18.4\%), while the percentages for Q2 was 10.0\%, 7.5\% for Q3 and 7.4\% for Q4 (Table 2). Even though only five journals were not above the $5.0 \%$ threshold of documents produced by international cooperation, it should be noted that only the Canadian Veterinary Journal - Revue Veterinaire Canadienne - presented a high percentage of documents published by researchers from one of the four major English-speaking countries. The other four journals did not reach a percentage of $2.8 \%$.

Table 2. Publication profile of veterinary journals.

1 of 2

\begin{tabular}{|c|c|c|c|}
\hline $\mathrm{N}^{\circ}$ & Journal title & $\begin{array}{l}\text { \% Docs from four main } \\
\text { Anglo-Saxon countries }\end{array}$ & $\begin{array}{l}\text { \% Docs International } \\
\text { cooperation }\end{array}$ \\
\hline 1 & Comparative Immunology Microbiology And Infectious Diseases & 31.2 & 17.9 \\
\hline 2 & Avian Pathology & 41.4 & 19.7 \\
\hline 3 & Reproduction In Domestic Animals & 12.2 & 17.6 \\
\hline 4 & Acta Veterinaria Scandinavica & 7.6 & 17.5 \\
\hline 5 & Fish Pathology & 4.8 & 9.4 \\
\hline 6 & $\begin{array}{l}\text { Canadian Journal Of Veterinary Research-Revue Canadienne De Recherche } \\
\text { Veterinaire }\end{array}$ & 78.6 & 8.5 \\
\hline
\end{tabular}


Table 2. Publication profile of veterinary journals.

\begin{tabular}{|c|c|c|c|}
\hline $\mathrm{N}^{\circ}$ & Journal title & $\begin{array}{l}\text { \% Docs from four main } \\
\text { Anglo-Saxon countries }\end{array}$ & $\begin{array}{l}\% \text { Docs International } \\
\text { cooperation }\end{array}$ \\
\hline 7 & Experimental Animals & 2.5 & 5.3 \\
\hline 8 & Revue Scientifique et Technique-Office International Des Epizooties & 39.2 & 19.0 \\
\hline 9 & Japanese Journal of Veterinary Research & 4.2 & 14.1 \\
\hline 10 & Revista Brasileira de Parasitologia Veterinaria & 4.6 & 8.8 \\
\hline 11 & Berliner Und Munchener Tierarztliche Wochenschrift & 2.7 & 9.2 \\
\hline 12 & Wiener Tierarztliche Monatsschrift & 3.2 & 8.5 \\
\hline 13 & Canadian Veterinary Journal-Revue Veterinaire Canadienne & 73.7 & 2.2 \\
\hline 14 & Acta Veterinaria Brno & 2.1 & 8.8 \\
\hline 15 & Schweizer Archiv Fur Tierheilkunde & 3.1 & 8.1 \\
\hline 16 & Vlaams Diergeneeskundig Tijdschrift & 2.9 & 6.5 \\
\hline 17 & Pesquisa Veterinaria Brasileira & 3.9 & 6.5 \\
\hline 18 & Revista Brasileira de Zootecnia-Brazilian Journal of Animal Science & 2.6 & 4.2 \\
\hline 19 & Revue de Medecine Veterinaire & 3.7 & 11.7 \\
\hline 20 & Archivos de Medicina Veterinaria & 8.1 & 16.5 \\
\hline 21 & Kafkas Universitesi Veteriner Fakultesi Dergisi & 1.1 & 2.1 \\
\hline 22 & Turkish Journal of Veterinary \& Animal Sciences & 2.8 & 5.4 \\
\hline 23 & Arquivo Brasileiro de Medicina Veterinaria e Zootecnia & 2.9 & 5.8 \\
\hline 24 & Pferdeheilkunde & 14.7 & 12.3 \\
\hline 25 & Revista Cientifica-Facultad de Ciencias Veterinarias & 3.7 & 11.4 \\
\hline 26 & Magyar Allatorvosok Lapja & 2.7 & 4.5 \\
\hline 27 & Tieraerztliche Umschau & 1.4 & 4.4 \\
\hline 28 & Kleintierpraxis & 4.2 & 5.4 \\
\hline
\end{tabular}

Source: Prepared by the authors (2016) based on data Web of Science (2014).

Note: The four Anglo-saxon countries considered are Australia, Canada, England and the United States. Data used to buld this table was extracted from Web of Science.

The four Anglo-Saxon countries were Australia, Canada, England and the United States. Data used to build table was extracted from WoS.

\section{Document type}

Since the impact factor is calculated using only the citations received by articles, reviews and 


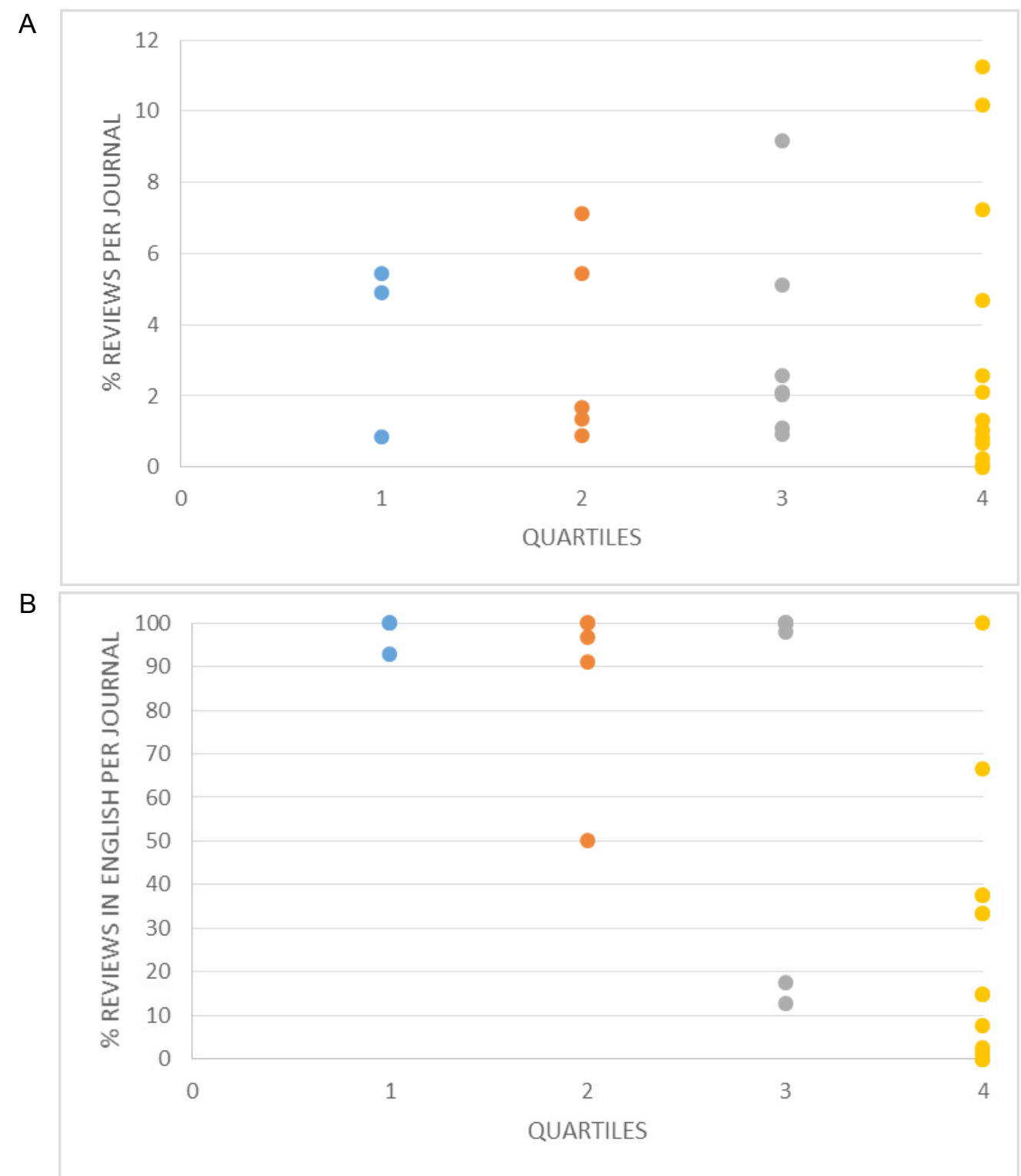

Figure 1. Ratio of reviews published by each journal.

Source: Prepared by the authors (2016) based on data Journal Citation Reports (2015) and Web of Science (2014).

Note: (A) Percentage of reviews published by each journal concerning the total amount of documents published between 1994-2003 and sorted by quartile. (B) Percentage of reviews published in English by each journal concerning the total amount of reviews published between 1994-2003 and sorted by quartile. Q: Quartile; Q1: first quartile; Q2: second quartile; Q3: third quartile; Q4: fourth quartile.

\section{Citation distribution}

We analyzed the citation distribution of articles published by 28 journals. Figure 2A shows that the degree of correlation between citation distribution and journal quartile was low. For instance, while two Q1 journals present a very low ratio of uncited documents, approximately $64 \%$ of the documents published by the third Q1 journal, Reproduction in Domestic Animals, have never been cited. Further analysis revealed that $92.3 \%$ of these uncited documents correspond to meeting abstracts that were published between the years 2005 and 2013. Conversely, approximately $20.0 \%$ of all the documents published by Q1 journals were cited more than 16 times between 1994-2013. As for Q2 journals, this group not only revealed the lowest ratio of uncited documents (12.3\% on average), but also that citation distribution was similar to the one found in Q1 journals (Figure 2B). The highest level of uncited documents was found in Q4 journals, followed by Q3. We expected to 
A

COMPARATIVE IMMUNOLOGY MICROBIOLOGY AND INFECTIOUS... AVIAN PATHOLOGY REPRODUCTION IN DOMESTIC ANIMALS ACTA VETERINARIA SCANDINAVICA FISH PATHOLOGY CANADIAN JOURNAL OF VETERINARY RESEARCH-REVUE CANADIENNE. EXPERIMENTAL ANIMALS REVUE SCIENTIFIQUE ET TECHNIQUE-OFFICE INTERNATIONAL DES.. JAPANESE JOURNAL OF VETERINARY RESEARCH

REVISTA BRASILEIRA DE PARASITOLOGIA VETERINARIA BERLINER UND MUNCHENER TIERARZTLICHE WOCHENSCHRIFT WIENER TIERARZTLICHE MONATSSCHRIFT CANADIAN VETERINARY JOURNAL-REVUE VETER INAIRE CANADIENNE ACTA VETERINARIA BRNO SCHWEIZER ARCHIV FUR TIERHEILKUNDE VLAAMS DIERGENEESKUNDIG TIJDSCHRIFT PESQUISA VETERINARIA BRASILEIRA REVISTA BRASILEIRA DE ZOOTECNIA-BRAZILIAN JOURNAL OF ANIMAL. REVUE DE MEDECINE VETERINAIRE ARCHIVOS DE MEDICINA VETERINARIA KAFKAS UNIVERSITESI VETERINER FAKULTESI DERGIS TURKISH JOURNAL OF VETERINARY \& ANIMAL SCIENCES ARQUIVO BRASILEIRO DE MEDICINA VETERINARIA E ZOOTECNIA PFERDEHEILKUNDE REVISTA CIENTIFICA-FACULTAD DE CIENCIAS VETERINARIAS MAGYAR ALLATORVOSOK LAPJA TIERAERZTLICHE UMSCHAU KLEINTIERPRAXIS
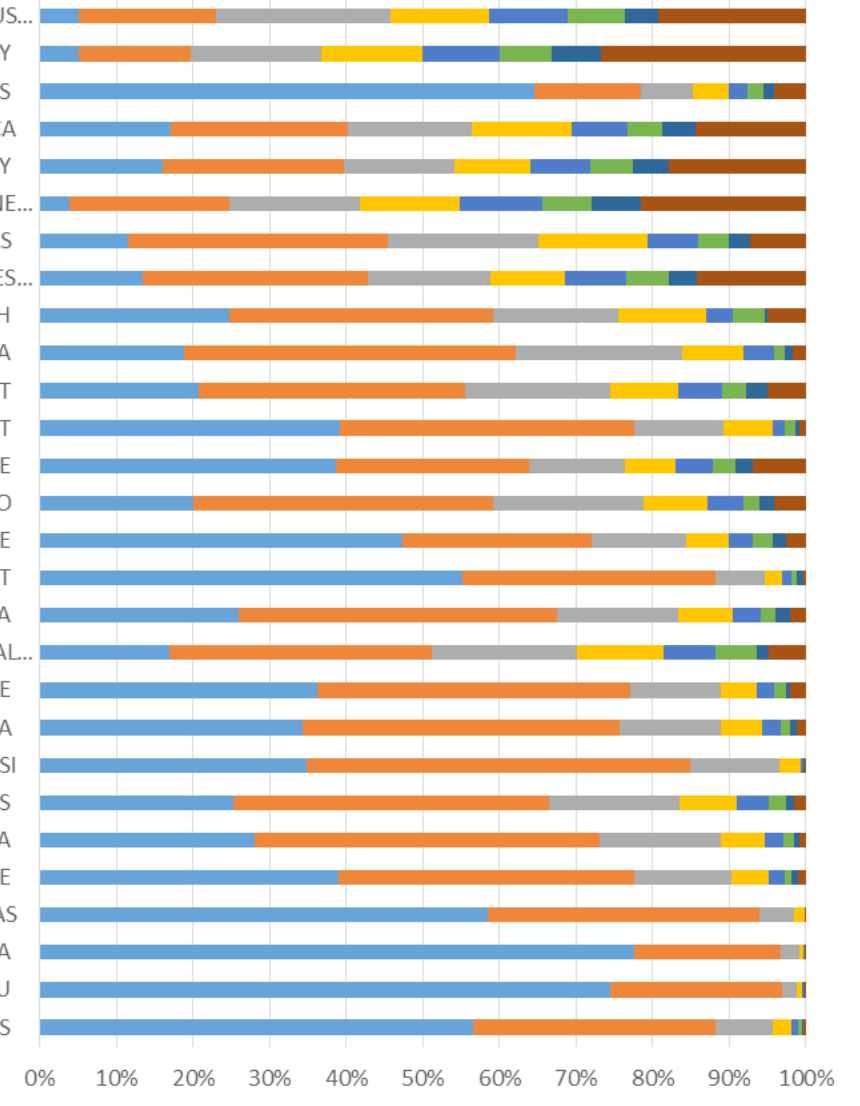

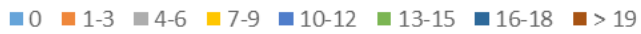

B

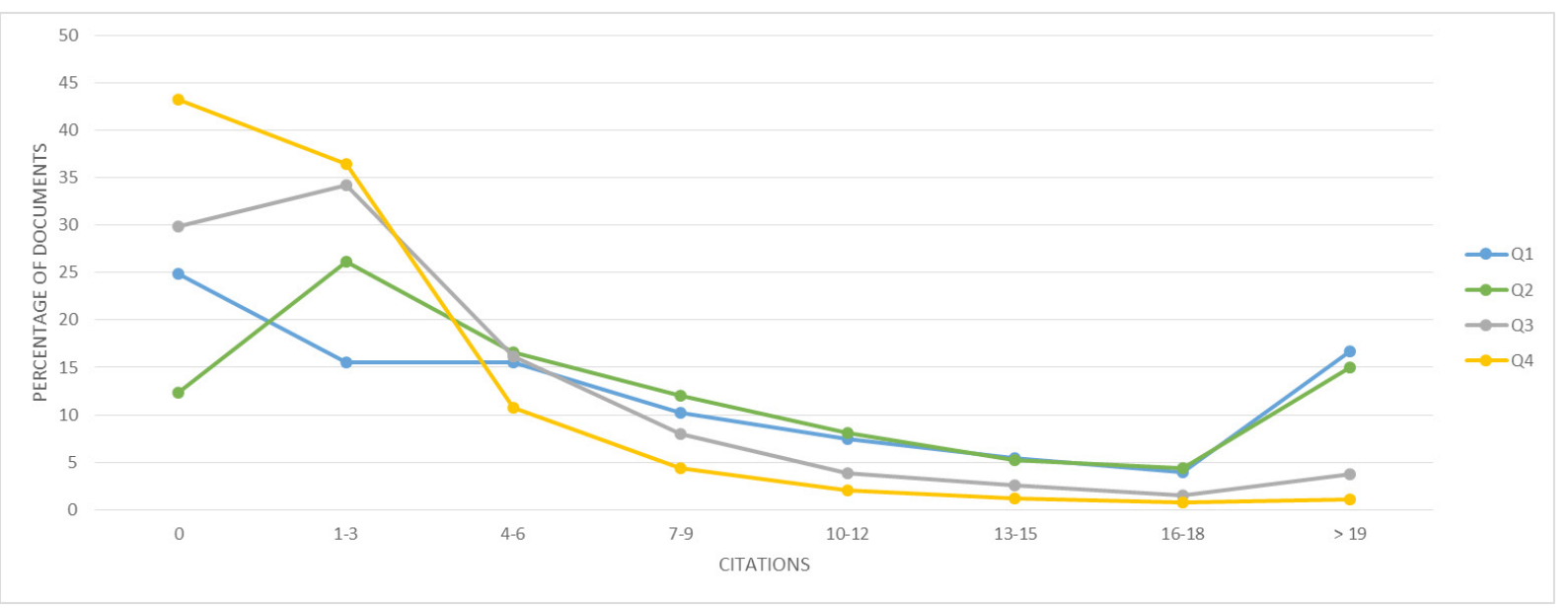

Figure 2. Citation distribution of journals.

Fonte Prepared by the authors (2016) based on data Journal Citation Reports (2014) and Web of Science (2014).

Note: A) Citation distribution of documents published by 28 journals. The legend indicates the number of citations received by group of documents. Black dotted lines separate the journals by quartile (Q1-Q4). B) The average percentage of documents was estimated for the 28 journals by quartile and plotted by the number of citations received. Q: Quartile. 


\section{Highly cited papers}

The citation pattern shown in Figure 2A reveals a highly skewed distribution, characterized by a few highly cited documents (or papers) and a large number of documents that were poorly or never cited, confirming a fact that has been previously described in the field of bibliometrics (AKSNES, 2003; BORNMANN, 2014). However, these differences diminish as the number of citations per document increase as we considered documents that received more than 19 citations.

Among the 48,118 documents published by the 28 journals included in this study, we identified five highly cited papers. These have been defined by Thomson Reuters as documents that have received enough citations to place them in the top $1 \%$ of its academic field (in this case Veterinary sciences) based on a high threshold for the field and publication year. Two of these documents were published by the journal Reproduction in Domestic Animals (Q1), one by the journal Wiener Tierarztliche Monastsschrift (Q3), one by the Canadian Veterinary Journal (Q3) and one by the Revista Brasileira de Zootecnia (Q4). An unexpected outcome of this analysis was that one of the five most highly cited papers was not written in English, but in Portuguese.

\section{Discussion}

In this study, a bibliometric analysis of multilanguage veterinary journals was addressed. It is a well-known fact that citation-based databases such as Web of Science and Scopus are biased towards Englishlanguage documents (ALBARILLO, 2014; MAS-BLEDA; THELWALL, 2016). Unfortunately, evidence has shown that documents written in a specific language tend to be cited in other documents by researchers who can read and understand that language (DAVAPARNA; BEHROUZFAR, 2009; LIANG et al., 2013; Ll et al., 2014).

According to JCR 2014, 27.1\% of the journals listed under the subject category "Veterinary Sciences" published documents in a language other than English. This percentage is similar (23.5\%) to the one established for "Agronomy", a related subject category, during the same year. These ratios are higher than those reported for non-English language journals (18.0\%) for the subject category "Medicine, general and internal" listed in JCR 2010 (VINTHER; ROSENBERG, 2012). However, the share of non-English documents in the medical sciences published by European countries has reduced significantly (VAN LEEUWEN et al., 2001), which may account for a smaller number of non-English language journals in this area.

The fact that the top ten journals (Table 1), according to their impact factor, published an average of $93.4 \%$ of their documents in English only confirms it as the universal language of science. Not surprisingly, the top three journals (ranked Q1) are managed by large commercial publishers aware of this fact. Differences in management have an effect on the nature of the published documents as commercial publishing companies design communication strategies to increase visibility and prestige of their journals (VELEZ-CUARTAS et al., 2016). On the other hand, academic management journals are usually managed by academics who dedicate part of their time to this endeavor. Nevertheless, increasing the impact factor should not be a sole argument for changing the publication language since some of the multi-language journals may play an important social role by providing information to local readers.

An analysis of the main countries that published in the subject category "Veterinary Sciences" throughout the 20-year period analyzed in this study revealed that the United States ranked first place, followed by England in the second place, Canada $\left(7^{\text {th }}\right)$ and Australia $\left(9^{\text {th }}\right)$. Therefore, we became interested in establishing their contribution to journals that stated publishing non-English studies. We found that these journals were from one of these four countries. In the case of the Canadian Veterinary Journal Revue Veterinaire Canadienne - $63.9 \%$ of all published documents were from Canadian researchers. As for the other Canadian journal - Canadian Journal of Veterinary Research - Revue Canadienne De Recherche Veterinaire, the percentage of Canadian documents was $53.0 \%$. However, these findings differ from those observed by an author from England. In the case of the journal Comparative Immunology Microbiology 
and Infectious Diseases, only $4.7 \%$ of all the documents were from British authors. Likewise, the percentage in the Avian Pathology journal was $16.8 \%$. It could be argued that because the last two journals are owned by large commercial publishers located in England, these estimates could be erroneous. Nevertheless, Fejes and Nylander (2014) reported that British authors published $69.0 \%$ of their articles in an England-based journal owned by a large commercial publisher.

An important editorial decision deals with the type of documents published by each journal. Since only citable documents (articles, reviews and proceedings) are considered to estimate the impact factor, we were interested in establishing the ratio of reviews published by each journal given that reviews are on average more cited than any other document types (Sigogneau, 2000). Our results (Figure 1) showed a low ratio of reviews published by Q1 journals and conversely a high ratio of reviews published by Q4 journals. Then, how come Q4 journals have not improved the impact factor of these journals? Further analysis revealed that the language of the reviews played a huge role. As Figure 1B shows, most of the Q4 journals publish non-English reviews, as opposed to Q1 and Q2 journals. In fact, the majority of non-English reviews published by Q3 and Q4 journals were poorly cited.

In contrast, the quantity of highly cited documents was very low for the 28 journals. Nevertheless, one of the documents was written in Portuguese so we analyzed which journals used the article published by Revista Brasileira de Zootecnia in 2008 as a source of information. A total of 175 articles and one review, from 26 different journals, used this highly-cited paper as a reference, 15 of which published documents only in English. Even though it may seem that the language barrier was not a limitation to readers, in reality all of these documents were authored by at least one Brazilian researcher, as our analysis revealed. This result corroborates the findings of Hicks (1999), who revealed that German and French sociology researchers tend to cite documents written in their own language. Perhaps, it may be in the interest of the authors to publish their study using their local language as their research may be focused on a domestic target.

\section{Conclusion}

In conclusion, our results confirm that the publication of documents in languages other than English are systematically less cited, even though these documents are indexed in international databases such as Thomson Reuters. At the end, readership seems to be reduced to a small group of researchers that dominate the language in which the document was written, as we proved with the highly-cited paper written in Portuguese. Researchers should be aware that if they choose to publish in their native language, their work might go unseen although it may be important to the field. One aspect that was not considered in this study was self-citation practices of the journals as this parameter affects the impact factor. A study considering this aspect could provide a different viewpoint on the language issue.

\section{Acknowledgments}

The research for this project was funded by Proyecto Fondecyt $n^{\circ} 1130918$ and Proyecto Financiamiento Basal PFB-016.

\section{Contribution}

All the authors contributed to the design of the study, data analysis and writing of the manuscript.

\section{References}

AKSNES, D. W. Characteristics of highly cited papers. Research Evaluation, v. 12, n. 3, p. 159-170, 2003.

ALBARILLO, F. Language in social science databases: English versus non-English articles in JSTOR and Scopus. Behavioral \& Social Sciences Librarian, v. 33, n. 2, p. 77-90, 2014.

BORNMANN, L. How are excellent (highly cited) papers defined in bibliometrics? A quantitative analysis of the literature. Research Evaluation, v. 23, n. 2, p. 166-173, 2014.

. 
DAVAPARNA, M. R.; BEHROUZFAR, H. International visibility of Iranian ISI journals: A citation study. Aslib Proceedings, v. 61, n. 4, p. 407-419, 2009.

FEJES, A.; NYLANDER, E. The Anglophone international(e): A bibliometric analysis of three adult education journals, 20052012. Adult Education Quarterly, v. 64, n. 3, p. 22-239, 2014.

HICKS, D. The difficulty of achieving full coverage of international social science literature and the bibliometric consequences. Scientometrics, v. 44, n. 2, p. 193-215, 1999.

JOURNAL CITATION REPORTS, 2014. Available from: <https:// jcr.incites.thomsonreuters.com/>. Cited: Jan. 10, 2016.

JOURNAL CITATION REPORTS, 2015. Available from: <https:// jcr.incites.thomsonreuters.com/> . Cited: Jan. 10, 2016.

KLOEZE, H; MUKHI, S. N.; ALEXANDERSEN, S. Swine influenza test results from animal health laboratories in Canada. The Canadian Veterinary Journal, v. 54, n. 5, p. 501-503, 2013.

KNIGHT-JONES, T. J.; RUSHTON, J. The economic impacts of foot and mouth disease: What are they, how big are they and where do they occur? Preventive Veterinary Medicine, v. 112 n.3-4, p.161-173, 2013.

LEWIS, M. et al. (Ed.). Ethnologue: Languages of the world. 19. ed. Dallas: SIL International, 2016. Available from: <http://www. ethnologue.com>. Cited: June 20, 2016.

LI, J.; QIAO, L.; LI, W.; JIN, Y. Chinese-language articles are not biased in citations: Evidences from Chinese-English bilingual journals in Scopus and Web of Science. Journal of Informetrics, v. 4, n. 8, p. 912-916, 2014.

LIANG, L.; ROUSSEAU, R.; ZHONG, Z. Non-English journals and papers in physics and chemistry: Bias in citations? Scientometrics, v. 95, n. 1, p. 333-350, 2013.

MAS-BLEDA, A.; THELWALL, M. Can alternative indicators overcome language biases in citation counts? A comparison of Spanish and UK research. Scientometrics, v. 109, n. 3, p. 2007-2030, 2016.

RABESANDRATANA, T. Plan for E.U. research funds raises ire. Science, v. 348, n. 6233, p. 379-380, 2015.

SCIMAGO. Display countries with at least. Scimago Journal \& Country Rank. 2015. Available from: <http://www.scimagojr. com/countryrank.php>. Cited: Mar. 2, 2017.

SIGOGNEAU, A. An analysis of document types published in journals related to physics: Proceeding papers recorded in the Science Citation Index database. Scientometrics, v. 47, n. 3, p. 589-604, 2000.

VAN LEEUWEN, T. N. et al. Language biases in the coverage of the Science Citation Index and its consequences for international comparisons of national research performance. Scientometrics, v. 51, n. 1, p. 335-346, 2001.

VASCONCELOS, S. M. R.; SORENSON, M. M.; LETA, J. Scientistfriendly policies for non-native English-speaking authors: Timely and welcome. Brazilian Journal of Medical and Biological Research, v. 40, n. 6, p. 743-747, 2007.

VINTHER, S.; ROSENBERG, J. Impact factor trends for general medical journals: Non-English-language journals are lagging behind. Swiss Medical Weekly, v. 142, w13572, 2012.

VELEZ-CUARTAS, G.; LUCIO-ARIAS, D.; LEYDESDORFF, L. Regional and global science: Publications form Latin America and the Caribbean in the ScieLO Citation Index and the Web of Science. El Profesional de la Información, v. 25, n. 1, p. 35-46, 2016.

WEB OF SCIENCE, 2014. Available from: <https://apps.webof knowledge.com/>. Cited: Jan. 10, 2016.

ZHOU, Y. The rapid rise of a research nation. Nature, v. 528, p. S170-S173, 2015. 